\title{
Experiences from establishing structured inter- and transdisciplinary doctoral programs in sustainability: a comparison of two cases in South Africa and Austria
}

\author{
Andreas Muhar \\ Doctoral School Sustainable Development and Institute of Landscape Development, Recreation and Conservation Planning, BOKU \\ University of Natural Resources and Life Sciences Vienna, Peter Jordan-Straße 82, 1190 Vienna, Austria. \\ Jan Visser \\ Learning Development Institute, Jupiter, Florida, USA. \\ John Van Breda \\ Transdisciplinary Sustainability Analysis, Modelling and Assessment Hub (TsamaHub) and School of Public Leadership \\ Stellenbosch University, Stellenbosch, South Africa.
}

\begin{abstract}
Inter- and transdisciplinarity is an essential research approach to address complex sustainability problems from a "science with society" perspective instead of the traditional approach of "science for society". We describe the specific challenges of integrating the principles of inter-and transdisciplinarity into doctoral studies using the example of two structured doctoral programs on sustainability in Europe (Austria) and Africa (South Africa). We compare the institutional setup, the management structure, the definition of the thematic focus areas and the student selection process. An important aspect is the design of a study program to introduce students to the core concepts and principles of inter-and transdisciplinary research and to prepare them for the empirical practice. Regular exchange between students and supervisors forms the basis for the development of a shared research culture. We conclude that critical issues for success are support by the university leadership, safeguarding of long-term funding, development of appropriate supervisory capacity and integration into existing academic structures and administrative processes.
\end{abstract}

\section{Keywords}

- Interdisciplinarity;

- Transdisciplinarity;

- Doctoral studies;

- Sustainability research

\section{Introduction}

\subsection{Purpose of the article}

We present and discuss experiences of designing and implementing structured inter- and transdisciplinary doctoral programs in sustainability. Most publications on transdisciplinary sustainability research are based on experiences from large collaborative projects (Balsiger, 2004, Bergmann et al., 2005, Hirsch Hadorn et al., 2006, Muhar et al., 2006, Scholz et al., 2006, Pohl and Hirsch Hadorn, 2007 and Hirsch Hadorn et al., 
2008). However, there is less literature in this specific context of inter-and transdisciplinarity in doctoral studies (e.g. (Mitrany and Stokols, 2005, Fry et al., 2006, Neuhauser et al., 2007, Tress et al., 2009, Graybill and Shandas, 2010 and Felt et al., 2012).

We address the challenges experienced in developing the capability to engage with academic and nonacademic societal stakeholders to achieve a transition towards a more sustainable society. By sharing our learning experiences in different geographical and cultural contexts we wish to invite critical reflection and discussion. Moreover, sharing our experience may provide stimulus to those who plan to get similarly involved.

\subsection{Sustainability: a challenge for re-orienting academic research and learning}

A need for innovation in doctoral programs arises from complex changes at the interface of humans and their environment. Morin and Kern refer to a "planetary polycrisis", a confluence of multiply interrelated crises with no single big problem generating all the other crises (Morin and Kern, 1999). Trying to resolve separately just one component is ineffective. Grasping the complexity is important when looking for solutions (Tainter, 2000, Kates et al., 2001 and Steiner and Laws, 2006). Inequitable access to increasingly limited resources such as food, water and energy, degradation of ecosystem services, disintegration of societal coherence, exuberant urbanization, progressive pollution and loss of biodiversity are all integral parts of this polycrisis.

Finding solutions to the polycrisis is a conditio sine qua non for sustaining human life on earth (Morin and Kern, 1999, Crutzen, 2002 and Sachs, 2007). Increased awareness has led to a growing concern with the manifold and often diversely interpreted dimensions of what is entailed by the notion of sustainability.

Formulating strategies to facilitate the transition to a more just and sustainable society (Swilling and Annecke, 2012), globally as well as locally, stands out in the debate. Numerous international initiatives and declarations emphasize the role of universities to take the lead by initiating solution-oriented research in these multiply interconnected areas (Cortese, 2003, Wright, 2004 and Lozano et al., 2011). Thus, the transition to a more sustainable society is a realistic vision to the extent that academia is capable of coproducing knowledge with, rather than for society. The institutional innovations and changes required of universities in this regard are far reaching.

In addition to its implications for academic research, the issue of sustainability is also important for inspiring new visions of learning. Chapter 36 of Agenda 21 adopted at the 1992 Earth Summit in Rio de Janeiro (United Nations, 1993), posits sustainable development as a major purpose to be held in mind while rethinking how and why humans learn. Education for Sustainable Development (ESD), a concept that emerged from the Earth Summit, thus looks beyond content at the development of such crucial competencies as critical thinking, imagining future scenarios and making decisions in a collaborative way (Morin, 1999 and UNESCO, 2006). Higher Education for Sustainable Development (HESD) is a still evolving, yet highly relevant subtopic of ESD, developing and adapting ESD concepts for the specific framework conditions at higher education institutions such as universities (Corcoran and Wals, 2004, Adomssent et al., 2006, Gough and Scott, 2007 and OECD, 2010). 


\subsection{Inter- and transdisciplinarity as methodological responses}

Sustainability problems are both ontologically and epistemologically complex, with many different disciplinary and non-disciplinary ways of understanding and defining what they are. We can no longer solely rely on a reductionist method, i.e. removing the problems from their context and analysing them in their 'atomistic' state (Hansson, 2012). Fundamental disciplinary knowledge of separate aspects of the polycrisis is of course essential, however, we must as well consider contextual and relational aspects. This requires new research approaches, moving not only across and between disciplinary boundaries, but also going beyond traditional boundaries of scientific practice by engaging with non-academic ways of understanding and knowing the world (Gibbons, 1994, Nowotny et al., 2001, Lozano, 2006, Pohl and Hirsch Hadorn, 2007 and Hirsch Hadorn et al., 2010).

This is not to compete with basic disciplinary knowledge production, but rather to explore and investigate problem areas using innovative ways and means, which are not necessarily within the scope and focus of mono-disciplinary research methods. Therefore, complementarity, rather than exclusivity, is a founding principle in developing inter- and transdisciplinary research approaches (Nicolescu, 1996).

In this context interdisciplinarity is usually defined as cooperation and cross-fertilization between disciplines, while transdisciplinarity aims at transcending the boundaries of disciplines and integrating the expert knowledge of science and the experiential knowledge of society; however, there is no universally accepted definition of these terms, and there are many other closely related terms in use as well. In fact, the literature presents a field in rapid evolution, full of lively and lasting debate (Gibbons, 1994, Klein, 1996, Balsiger, 2004, Max-Neef, 2005, Frodeman, 2010, Scholz, 2011 and Bergmann et al., 2012). Evolving empirical research and on-going critical reflection may settle these issues.

Another debate, which is at least two decades old, is on the consequences of introducing inter- and transdisciplinary studies at universities, in particular regarding required research capabilities, attitudes, practices and mindsets of academic researchers (Boyer, 1990, Grunwald, 2004, Visser, 2006, Adomssent et al., 2007, MacMynowski, 2007, Woods, 2007, Wiek et al., 2011 and Rieckmann, 2012).

Summarizing this discussion for our topic, we conclude that the following areas need to be addressed in curricula and research practice, to be finally reflected in structural changes:

Integration capability: Being appreciative of the potential value of different disciplinary and non-disciplinary contributions, and being able to integrate them.

Innovative methodological capability: Having the ability to tackle the complementarity of methodologies such as quantitative, qualitative and transformative approaches - and to find the right balance between them.

Communicative capability: Being able to generate and negotiate new concepts and representations capable of forging shared understanding across disciplinary divides and transcending the schism between science and society.

Mutual learning capability: being able to learn with society in different contexts how to develop shared problem framing of both real-world and research problems, including research questions and strategies. 


\subsection{Specifics of doctoral research}

The essence of doctoral training is "advancement of knowledge through original research" (European Ministers Responsible for Higher Education, 2005). Doctoral candidates are seen both as students and early career researchers. Research, in this context, is to be contemplated against the backdrop of the following polarities:

Supervised vs. independent research: Doctoral candidates need to prove their ability to conduct research on their own, nevertheless they also need guidance in all phases of their project and should profit from their supervisors' experience and advice. Students and supervisors need to clarify their relationship, in particular regarding the supervisory management style ( Gatfield, 2005 and Mainhard et al., 2009).

Teamwork vs. individual achievement: Today most academic research is designed as a complex collaborative process. Researchers need to work as a team, sharing ideas, data and findings to inspire their collaborative explorations. However, in doctoral theses, the achievements of the individual researcher as major assessment components must be clearly identifiable.

Tradition vs. originality: When doctoral research is conducted in the context of a well-established school, a tendency towards alignment with the traditions of the respective school might develop, which can conflict with new, unconventional approaches.

There is a multitude of organizational formats for doctoral studies, influenced by disciplinary practices and national traditions (Clark, 1995). The classical European model has been a one-on-one relationship between student and supervisor. The German term Doktorvater ("Doctoral Father") characterizes the sometimes rather paternalistic connotation of this relationship quite clearly. Doctoral theses conducted under such conditions are predominantly mono-disciplinary and not connected to other projects. Coursework plays a minimal role. In the USA, various models of structured doctoral programs have evolved ("Graduate Schools"), usually with more emphasis on systematic preparation through coursework and coordination between individual theses. In Europe, the "Bologna Process" aims at harmonizing academic degree and quality assurance standards. Doctoral studies should be improved by providing better institutional conditions such as structured doctoral programs ( Teichler, 2006).

A critical issue of doctoral studies is funding: Conducting a multi-year project without funding for living costs, tuition and research related expenses is hardly possible. Direct scholarships provide means to develop projects individually. Doctoral research is also often conducted as part of projects funded e.g. by industry, where the thesis is rather a by-product, and the freedom of the students also more limited (Guth, 2006).

\section{Empirical basis}

In this paper we analyze two doctoral programs, one each from Europe and Africa. The authors have been involved in the development, management and implementation of these programs. As participantobservers they thus have detailed knowledge of each of them. The programs are sufficiently diverse to be of interest in a comparative study. We start off with a brief description of each of the two cases: 
The Doctoral School of Sustainable Development (Doktoratskolleg Nachhaltige Entwicklung, dokNE) ${ }^{1}$ at BOKU University of Natural Resources and Life Sciences, Vienna, Austria: BOKU is a research oriented university with about 1200 staff and 10,000 students, offering study programs related to primary production, engineering, biotechnology, and planning. DokNE was established in the framework of the Austrian Sustainability Research Program proVISION, ${ }^{2}$ and jointly funded by BOKU, the Federal Ministry of Science and Research, the Ministry of Agriculture, Forestry, Environment and Water Management, and the Provinces of Vienna, Lower Austria and Styria. In its first period (2007-2010), 15 employed PhD candidates, 18 Masters students and one postdoc worked on projects at the interface between spatial development, climate change, quality of life, and tourism, guided by supervisors from ten different departments. A second cohort started in 2011.

The Transdisciplinary Doctoral Programme in Sustainability (TdDPS) at Stellenbosch University (SU), South Africa: SU is a highly reputable research university. It gave birth to the Afrikaans language and was also known for supporting the Apartheid regime. Since 1994 SU has redefined itself as a constructive entity for an emerging democratic society. The Transdisciplinary Sustainability Analysis, Modelling and Assessment Hub (TsamaHub) is a lead activity of SU's "The Hope Project". It is an academic and research centre with multiple external partners, including the Council for Scientific and Industrial Research (CSIR), ${ }^{3}$ the Human Sciences Research Council (HSRC) ${ }^{4}$ and the Sustainability Institute (SI). ${ }^{5}$ Within the university, it is linked to many different faculties, providing the basis for joint supervision of inter-and transdisciplinary theses tackling the wide range of sustainability challenges that Africa faces. In 2010 a first cohort of 12 candidates was admitted to the program. A second cohort entered the program in 2012.

Both programs, though established in starkly different geographic and cultural environments, have been in regular contact with each other. Mutual visits, discussions with teachers and students, and involvement in teaching provided the authors of this paper with a good empirical knowledge base of both cases. Sharing the interest in transition to a more just and sustainable society, both programs focus on empirical, solutionoriented transdisciplinary research. The opportunities for critical theory-building, reflected in different parts of this article, are the result of being solution-oriented and reflective at the same time.

\section{Findings and commentary}

\subsection{Establishment of the programs6}

\subsubsection{Institutional challenges and arrangements}

At both universities, research on different aspects of sustainable development was well established before introducing the doctoral programs. The new entities therefore aimed at linking existing activities and coordinating research directions by fostering interdisciplinary cooperation. Transdisciplinary research methodology and principles, however, were new for part of the faculty.

To make engagement attractive for faculty, all performance indicators achieved in the doctoral program (e.g. completed theses, publications) are accredited to the participating researchers and their departments.

Both programs had to meet the general regulations regarding doctoral studies at their university. All thesis projects needed approval by the responsible boards. At BOKU, two different doctorates are offered, a technical/natural science degree and a socio-economic degree. Depending on the disciplinary background, some students had to pass additional courses as entry requirements for these programs. For them this 
created a significant additional workload and a feeling that not all disciplines were equally valued, which was in contradiction to the interdisciplinarity claim of the program and to the original advertisement inviting applications from all disciplines.

In contrast, at SU, individual doctoral degrees are offered by each Faculty. Admission into TdDPS did not mean automatic registration of the student's research proposal by a particular faculty. For example, without the formal under- and post-graduate qualifications required by the Health Sciences Faculty, it is not possible to register for the Health Sciences doctorate. In some cases students had to adjust research topics to allow registration in a different faculty, whilst retaining the students' original broad interest in their respective topics.

\subsubsection{Internal management structure}

In dokNE, a coordination team consisting of the program coordinators and three doctoral students discussed all relevant management issues. The major evaluative structure was the advisory board consisting of the Vice-Rector Research, representatives from funding partners, international experts, and representatives from NGOs engaged in practical sustainability work. This board looked both at the progress of the school and of individual thesis projects; positive annual evaluation was required for continuing the employment contracts. The advisory board proved to be very valuable. The scientific and the practice experts were very supportive in developing the projects. Their external perspective was also helpful in focussing the theses. In preparing their first year reports, many students felt obliged to "pack everything into the project" with regard to the dokNE research principles of inter-and transdisciplinarity. The board soon realized that the students might promise too much, and recommended a redesign to realistic dimensions.

At SU the program started later and is thus less advanced in its development than dokNE. During the setup phase, all relevant issues were being discussed by an interim group of academics. Since the adoption of the constitution of the TsamaHub as a university centre, a management committee is responsible for day-today management; longer-term strategic issues are the responsibility of the governing body.

\subsubsection{Definition of research focus and selection of students}

Transdisciplinary doctoral programs distinguish themselves from traditional PhD programs by attracting students interested in researching complex problems in which the human, the social and the environmental aspects cannot be separated. In dokNE, thesis topics had been pre-defined by the teachers and the funding partners. Applicants could register for up to two advertised projects. The inter- and transdisciplinary character was clearly communicated, and there were no formal restrictions regarding the applicants' disciplinary background. All study areas were located in Austria. To interact with local stakeholders, applicants thus had to be fluent in German. They had to submit a short project sketch, including relevant literature and the proposed methodology. Out of 250 applications, 180 met the formal criteria and were evaluated by three faculty members responsible for the respective topic. 45 candidates were invited for presentations and interviews; 15 were finally accepted and, according to Austrian funding regulations, offered an employment contract.

In TdDPS prospective students were encouraged to submit pre-proposals within broad sustainabilityoriented research themes prepared by the TsamaHub academics. Individual candidates had to develop their 
own topic ideas using these themes as framework and guideline. Of the 69 applications 37 met the formal SU criteria for entry into the PhD program. A panel of 20 academics evaluated them. 17 candidates were invited for an interactive session with the academics. After presenting their project sketches they were given a choice of case studies to work on in small groups, as the supervisory panel wanted to see how the applicants would perform within a team. Finally, 10 students were admitted to the program.

\subsection{Setting the conditions for a shared research culture}

It was envisioned that graduates should not only become competent researchers, but also be capable of solving complex sustainability problems in both academic and non-academic settings. This requires an environment fostering creativity and imagination (Montuori, 2011) as well as scholarship in knowledge generation, but also in integration, engagement and teaching (Boyer, 1990).

When an institution aims at bringing together teachers and students from different disciplines, there is the need to work towards shared understanding of the key principles, in our cases regarding sustainability and inter- and transdisciplinary research methods. It would of course be narrow-minded and naive to impose uniform definitions on the whole group; rather participants were exposed to the broad range of definitions, and invited to discuss implications of the implementation of different concepts.

A critical issue in this context is the discussion of standards regarding "good scientific practice": both students and teachers have all been socialized in their home disciplines' normative traditions (Becher and Trowler, 2001), often not even aware of that. Missing out on such clarification can later lead to severe conflicts, e.g. when it comes to the selection of research methods.

\subsubsection{Introducing core concepts and principles}

Both the greatest challenge and the most favourable opportunity in developing a core curriculum for an inter- and transdisciplinary doctoral program is the heterogeneity of the participants' knowledge and sociocultural backgrounds.

In dokNE, three credit-bearing courses were initially designed to help students develop a joint understanding of key principles and approaches:

- Methods of inter- and transdisciplinary research: In the first semester students were introduced to the range of definitions of inter-and transdisciplinarity and to methods applied in this context such as systems analysis and scenario technique. Discussions arose if it is possible at all to apply the experiences from large collaborative research projects to doctoral projects: Can one single person conduct an interdisciplinary project, i.e. can a person educated in one disciplinary paradigm adopt another discipline's way of thinking and integrate both? What are the quality standards of inter-and transdisciplinary projects in comparison to standard mono-disciplinary projects?

- Methods of Social Sciences: Transdisciplinary stakeholder integration often implies the application and integration of social sciences methods. Students should thus be familiar with the principles of research design and data collection as practiced in the social sciences. The teaching team of this second semester course consisted of a political scientist with background in economics and forestry, a landscape planner with focus on tourism research, and a transport scientist with background in 
physical planning. Thus, there was heterogeneity both among the students and the teachers. It was extremely difficult to run this course, as the positions were often contradictory, e.g. in the debate about the choice between qualitative and quantitative research methods. While academically such debates may be necessary and possibly fruitful, in the reality of that particular class it was rather perceived as frustrating and unsettling.

- Data Analysis Methods: Similar to the idea of the above mentioned course, the intention of this subject was to introduce the students to generic concepts of data analysis both in natural and social sciences. However, based on the above negative experiences students proposed dropping this as a common subject. Instead, they requested in-depth courses addressing their specific individual data analysis needs (e.g. qualitative content analysis, geographic information analysis).

At $\mathrm{SU}$, contrary to BOKU, the thesis is the only credit-bearing program component, which means that all TdDPS courses are non-credit bearing modules. For developing a shared understanding of the principles and approaches to sustainability and transdisciplinarity, four full-week modules were offered at the start of the program:

- Sustainability Challenges in Africa: Students were first exposed to the African polycrisis relating to issues of poverty, climate change, urbanization, energy, water and food security, natural resource depletion, human health, power and conflict, gender inequality, loss of identity and relational values. Coming face to face with the polycrisis and its consequences for the future of the continent triggered a debate on the redefinition of the role of science in society. Students realized that it is no longer useful to approach these as separate problems to be studied from different monodisciplinary perspectives. Thus the notion of 'science for society' changed to 'science with society'.

- Complex Systems and Complexity Theory: Students were given a thorough overview of the core concepts of complexity theory in general. A key concept is that of emergent properties that are not necessarily present in the individual things themselves, but which come into view in the relationships between things. Students were given the challenge to apply these insights to the context of sustainability and particularly to their own projects. The challenge to both distinguish and translate complex societal problems into manageable research questions proved to be really tough as this implies some unavoidable reductionism.

- Research Paradigms, Methodologies and Methods: Students were given a general overview of the major research paradigms such as positivism, empiricism, rationalism, interpretivism, constructivism etc. They were stimulated to critically reflect upon the ontological and epistemological assumptions of these paradigms when faced with the challenge of having to borrow from and bring together disparate research methods.

- Transdisciplinarity and Transdisciplinary Research: This module started with building awareness about what makes good research in general. Issues of validity, reliability, and generalizability were discussed. Students were encouraged to think creatively about ways to get socially useful answers to research questions, rather than just choosing methods from a set menu of different methodological options. Transdisciplinarity was discussed as a methodological setting for integrating different knowledge and value systems for co-producing knowledge with society. The focus then shifted to the challenges facing individual transdisciplinary research projects. Standing out in these discussions were the constructive ideas generated by students on how to incorporate the broad principles of transdisciplinarity into their own research. 
The four weeks of these introductory modules provided a good foundation for the doctoral program. Yet it was also found to be demanding.

\subsubsection{Research seminar as regular exchange platform}

Every doctoral school needs a central forum of debate. In both programs a two-weekly research seminar provides the framework for discussing the progress of individual projects as well as general current issues of sustainability research. External guests are important as critics and creative minds bringing in new perspectives. Responsibility for setting up the seminar format, for detailing the program and chairing the sessions was shared among teachers and students. In TdDPS these research seminars played a particularly important role in helping the students to develop their research proposals up to the point of submitting these for approval in their faculties of registration.

\subsubsection{Informal training courses}

Graduates of both programs are expected to become competent in the wider field of participatory processes of producing and sharing sustainability related knowledge. In dokNE, various non-credit-bearing courses were offered to prepare them for the challenges posed by engaging in these processes, such as public relations, project management, group moderation, and communication with different audiences. In TdDPS, a Summer School was organized in the second year to prepare students for embarking on their individual research processes. The focus was on the practical side of how to do joint problem framing and to formulate research questions that may both contribute to the transformation of real-world problems and produce new scientific knowledge.

\subsubsection{Team building}

Integration of different social, geographic and disciplinary backgrounds is crucial for forming an interdisciplinary team. Team building occurs both in formal settings (courses) and in informal interaction (Wall and Shankar, 2008 and Ryser et al., 2009). In both programs, students were encouraged to meet regularly outside their work life. About half the students were graduates from these universities; they willingly introduced the newcomers to local peculiarities and traditions. In dokNE, a planning retreat in the first week in a remote resort provided a good opportunity for getting to know each other; later on, a monthly open "club" meeting was organized as an opportunity for informal exchange between students and supervisors. Activities organized by the students included joint cooking, skiing weekends and hiking trips. In TdDPS initial team building was a by-product of the participation in the interactive core modules. It remained a central concern of subsequent informal meetings held every second week, alternating with the above mentioned research seminars. These meetings were self-organized and took on the form of open discussions on issues that the group considered important to explore, occasionally followed by sharing a meal.

\subsubsection{Organizing everyday work}

The physical office space and the social environment are important aspects of any working situation. In a cross-departmental context there is often debate, whether participants should be placed all together in the same location to stimulate exchange within the group or rather placed across the departments to provide better integration among the departments. 
DokNE decided to place the students in the departments with a yearly rotation, so that they could experience different working environments and communicational habits. As academics rarely change departments within a university, this rotation also provided insights for the supervisors on how others organize their daily working life. In practice it was not always possible to conduct this rotation, as not all working environments were equally attractive, which led to some friction.

In dokNE, crosscutting groups were formed to incur tasks relevant to all students, such as data management (e.g., data storage, backup strategies), external communication (e.g. web design, production of brochures and annual reports, maintaining media contacts) and training (e.g. organization of specific courses, programming of research seminars). These groups not only contributed significantly to making the program work, but also fostered team building.

\subsection{Development of individual thesis projects}

Implementing the principle of transdisciplinary stakeholder integration in an individual doctoral thesis project poses challenges both for the academic institution (Muhar and Kinsperger, 2007) and for the student (Felt et al. 2012). Ideally, case actors should be involved in all the following stages of the research process: (1) problem framing (definition, analysis and structuring, hypotheses, research questions); (2) design of methodology and selection of methods; (3) data collection, analysis and interpretation; (4) development of solutions and recommendations; (5) dissemination and communication of findings; and (6) implementation. In many projects, stakeholders would already have been involved in the case before the researchers entered the scene (Enengel et al. 2012).

Therefore it is crucial that the doctoral students and the various transdisciplinary partners get into contact soon. In TdDPS, during the first year of writing their research proposals for admission by a particular Faculty the actual involvement of case actors left to be desired. This became clear during the Summer School in the second year when this crucial aspect was dealt with more thoroughly. This meant that the students had to see their 'approved' research proposals merely as provisional problem statements which still required to reflect an intensive process of stakeholder engagement in order to generate a shared research object for translation into research questions (Jahn, 2008). In contrast, at dokNE, most projects had originally been developed by the supervisors in cooperation with local government authorities, thus creating the need to integrate the students into an ongoing development process. The involvement of the local authorities was particularly helpful in providing access to data, identifying local key actors and facilitating access to local social networks.

It is often argued that transdisciplinary approaches provide a wider perspective of a research problem by integrating expert and experiential knowledge. However, there is a catch. Specific interests of case actors can significantly influence the course of a project. Besides, core scientific interest in a topic may conflict with the demands of local actors. Students therefore need specific assistance in navigating in this field of boundary work between science and society (Lieven and Maasen, 2007 and Pohl et al., 2010).

A helpful instrument in dokNE were scholarships for Masters theses to meet three objectives: (1) to introduce younger students to the principles of transdisciplinary research and prepare the ground for a next cohort of doctoral students; (2) to assist in data collection for the doctoral projects; and (3) to provide possibilities to focus on side aspects with specific relevance for individual actor groups. 
Generalizability is a crucial issue in any kind of case-oriented research (Yin, 2002, Flyvbjerg, 2006 and Krohn, 2008). PhD students who are enthusiastically engaged in their cases can easily get lost in the specific situation of their projects. They therefore need an external perspective of their case. In dokNE's case international corresponding projects were identified with which the students should cooperate, e.g. by way of joint data analysis or comparative publications. Ideally, these projects should have been both on similar topics and in similar project phases, but in different geographic or cultural environments. It was the supervisors' responsibility to identify such projects from their own international networks, as it is difficult to find research projects in early stages of development, i.e. before the release of first publications.

Supervisors often learnt about such projects at conferences.

Presentation and publication of results is critical in academic research. When setting up the dissemination strategy for each doctoral project, it was necessary to consider both scientific and extra-scientific audiences. While both programs defined themselves as interdisciplinary, the publication traditions of the individual disciplines still had to be accounted for; this refers also to the thesis format: In the natural sciences a thesis by journal publications is very popular; in the social sciences the classic monograph is still predominant. A significant challenge was to identify appropriate channels to communicate with the local communities and the general public. According to the context of each project, the students implemented a large variety of formats such as publication in local newspapers, preparation of brochures, presentation to local authorities and communities, and participation in informal discussions at local feasts. All these activities require a considerable amount of time, which can be in competition with scientific publications. Finding the right balance between these two kinds of activity was very challenging.

\section{Discussion and conclusions}

Establishing transdisciplinary structured doctoral programs in sustainability research is a challenging exercise for those seeking innovation in academic teaching. In the preceding sections we discussed the specific experiences from two cases. Based on what we learnt and on our exchange with colleagues from similar institutions we now discuss the main organizational challenges for universities intending to create transdisciplinary doctoral programs more generally. However, other universities should not seek to replicate any of the two models, but rather have our conclusions in mind as they consider their own circumstances and explore their own options. After all, the dokNE model could not have worked well at SU and vice versa. As is often the case in the diffusion of innovation, things must be reinvented in context.

Support by university leadership: The establishment of a structured doctoral program across the boundaries of existing units (faculties, departments) has many implications for administrative structures and processes at various levels of the hierarchy. Therefore the backing from the university's leadership is crucial ( Lozano, 2006). Initially it may be sufficient for leaders to personally express their support; however, in the long run this needs to become visible in official strategic documents. When recognized by the leadership as a strategic project, administrators will more likely be willing to search for unconventional solutions to practical administrative problems. For the supervisors it is important that their engagement is not regarded as a "hobby" outside their normal work obligations. Rather, it should be seen as an important contribution to the university's development strategy.

Long-term safeguarding of funding: Structured doctoral programs offering scholarships or employment contracts to students are expensive. In both our cases the programs started off on seed funding with significant contributions from outside the normal university budget. For subsequent phases it is essential to 
change to a longer-term funding perspective. Here again the commitment from the university leadership is decisive to secure internal funding as well as to maintain relationships with external funding entities.

Developing the supervisory capacity: Not all supervisors are experienced enough, capable and willing to engage in inter- and transdisciplinary research. Co-supervision from other institutions can help to extend the limited capacity and provide additional inputs from different perspectives. At an informal level, personal relationships between supervisors can help overcome barriers. However, also formal provisions are necessary: Internal faculty development programs at universities rarely address the challenges for supervisors to teach in such environments. It is thus necessary to provide training for prospective supervisors on principles and practices of transdisciplinary research when embarking on a transdisciplinary doctoral program. Developing shared understanding is obviously useful. However, it should leave room for individual and context-specific adaptations.

Institutionalization: A doctoral program aiming at integrating different disciplinary paradigms, and finally transgressing them, is difficult to institutionalize. Establishing a new unit equivalent to other existing structures (departments etc.) may provide a good internal visibility, power of decision and access to resources. However, it can also eventually lead to separation and isolation. The alternative is a crosscutting horizontal structure trying to interweave existing units. This means a significant dependence on the wellestablished units but it may help to slash encrusted internal barriers between these structures. An important prerequisite for this model is the attribution of success indicators (e.g. number of publications, amount of external funding) to the supervisors' home units.

Adapting administrative procedures: Study related procedures such as curriculum development, definition of admission and performance standards, and approval of thesis proposals are often organized along disciplinary lines. It can be difficult to have an inter- or transdisciplinary thesis proposal accepted by a disciplinary study board if there is no suitable procedure in place for such a case. Central administrations are often overstrained to deal with non-conventional admission cases ("problem cases"). It is therefore essential to include the administration in the development of such cases right from the beginning.

Curriculum design and organization: Doctoral programs are a hybrid between teaching and research activities. For many students and supervisors the research component is much more relevant, while coursework is often seen as an unnecessary additional burden. In inter-and transdisciplinary programs students coming from a specific disciplinary background cannot be expected to be familiar with principles and methods of inter- and transdisciplinary research. Introductory courses, credit-bearing or not, are therefore essential. With small numbers of students in the program, it might be problematic to justify the funds for such courses. It can thus be useful to allow students from other programs, interested in a wider perspective of integration, to attend as well. Courses offered in inter-and transdisciplinary programs could thus inseminate other programs and contribute to the implementation of the principles currently discussed in the context of the Curriculum Reform Manifesto. ${ }^{7}$

Concluding we emphasize that the establishment of an inter-and transdisciplinary doctoral program on sustainability must be part of a more general discussion about the role of the university in society (Fadeeva and Mochizuki, 2010). According to the principles of transdisciplinarity, the university is challenged to engage in both an internal dialogue and a dialogue with society on its role in creating a sustainable world. Such a process cannot be decreed top-down by a single university leader, nor can it be achieved by individual students or researchers bottom-up without support from the leadership. 
If the university wants to contribute to a more sustainable society through scientific knowledge production, then it cannot resort to the proverbial 'fence sitting' in the name of 'scientific objectivity'. The university must recognize its societal responsibility. When the leadership, students and researchers together acknowledge this and no longer shy away from engaging with 'wicked' (Rittel and Webber, 1973) sustainability problems, then the institution university will also support establishing 'laboratories of mutual learning' and allow them to flourish; one such contribution can then also be an inter-and transdisciplinary structured doctoral program on sustainability.

\section{Acknowledgements}

The working phase 2007-2010 of the Doctoral School Sustainable Development at BOKU University of Natural Resources and Life Sciences Vienna, Austria, was jointly funded by the Austrian Federal Ministry of Science and Research, the Ministry of Agriculture, Forestry, Environment and Water Management, and by the Provinces Lower Austria, Vienna and Styria in the framework of the Austrian Sustainability Research Program proVISION. For the Transdisciplinary Doctoral Programme in Sustainability at Stellenbosch University three scholarships were provided to non-South African students by the Discretionary Fund of the Vice-Rector Research. The Council for Industrial and Scientific Research (CSIR) funded two more students.

\section{References}

1. Adomssent et al., 2006 M. Adomssent, J. Godemann, A. Leicht, A. Busch Higher Education for Sustainability - New Challenges from a Global Perspective VAS, Frankfurt, M. (2006)

2. Adomssent et al., 2007 M. Adomssent, J. Godemann, G. Michelsen Transferability of approaches to sustainable development at universities as a challenge International Journal of Sustainability in Higher Education, 8 (4) (2007), pp. 385-402

3. Balsiger, 2004 P.W. Balsiger Supradisciplinary research practices: history, objectives and rationale Futures, 36 (4) (2004), pp. 407-421

4. Becher and Trowler, 2001 T. Becher, P. Trowler Academic Tribes and Territories: Intellectual Enquiry and the Culture of Disciplines Open University Press, Philadelphia, PA (2001)

5. Bergmann et al., 2005 M. Bergmann, B. Brohmann, E. Hoffmann, M.C. Loibl, R. Rehaag, E. Schramm, J.-P. Voß Quality Criteria of Transdisciplinary Research - a Guide for the Formative Evaluation of Research Projects Institute for Social-Ecological Research (ISOE), Frankfurt am Main (2005)

6. Bergmann et al., 2012 M. Bergmann, T. Jahn, T. Knobloch, W. Krohn, C. Pohl, E. Schramm Methods for Transdisciplinary Research A Primer for Practice, Frankfurt/New York (2012)

7. Boyer, 1990 E.L. Boyer Scholarship Reconsidered: Priorities of the Professoriate Carnegie Foundation for the Advancement of Teaching, Princeton, N.J. (1990)

8. Clark, 1995 B.R. Clark Places of Inquiry: Research and Advanced Education in Modern Universities University of California Press, Berkeley (1995)

9. Corcoran and Wals, 2004 P.B. Corcoran, A.E.J. Wals Higher Education and the Challenge of Sustainability: Problematics, Promise, and Practice Kluwer Academic Publishers, Dordrecht; Boston (2004)

10. Cortese, 2003 A.D. Cortese The critical role of higher education in creating a sustainable future Planning for Higher Education, 31 (3) (2003), pp. 15-22

11. Crutzen, 2002 P.J. Crutzen Geology of mankind Nature, 415 (6867) (2002), p. 23

12. Enengel et al., 2012 B. Enengel, A. Muhar, M. Penker, B. Freyer, S. Drlik, F. Ritter Co-production of knowledge in transdisciplinary doctoral theses on landscape development - an analysis of actor 
roles and knowledge types in different research phases Landscape and Urban Planning, 105 (2012), pp. 106-117

13. European Ministers Responsible for Higher Education, 2005 European Ministers Responsible for Higher Education The European Higher Education Area - Achieving the Goals (Bergen Communiqué) (2005)

http://www.ond.vlaanderen.be/hogeronderwijs/bologna/documents/MDC/050520 Bergen Comm unique1.pdf

14. Fadeeva and Mochizuki, 2010 Z. Fadeeva, Y. Mochizuki Higher education for today and tomorrow: university appraisal for diversity, innovation and change towards sustainable development Sustainability Science, 5 (2) (2010), pp. 249-256

15. Felt et al., 2012 U. Felt, J. Igelsböck, A. Schikowitz, T. Völker Growing into what? The (Un-)disciplined socialisation of early stage researchers in transdisciplinary research Higher Education (2012) http://dx.doi.org/10.1007/s10734-10012-19560-10731

16. Flyvbjerg, 2006 B. Flyvbjerg Five misunderstandings about case-study research Qualitative Inquiry, 12 (2) (2006), pp. 219-245

17. Frodeman, 2010 R. Frodeman The Oxford Handbook of Interdisciplinarity Oxford University Press, Oxford; New York (2010)

18. Fry et al., 2006 G.L.A. Fry, B. Tress, G. Tress PhD students and integrative research B. Tress, G. Tress, G.L.A. Fry, P. Opdam (Eds.), From Landscape Research to Landscape Planning - Aspects of Integration, Education and Application, Springer, Dordrecht (2006), pp. 193-205

19. Gatfield, 2005 T. Gatfield An investigation into PhD supervisory management styles: development of a dynamic conceptual model and its managerial implications Journal of Higher Education Policy and Management, 27 (3) (2005), pp. 311-325

20. Gibbons, 1994 M. Gibbons The New Production of Knowledge: the Dynamics of Science and Research in Contemporary Societies SAGE Publications, London; Thousand Oaks, Calif (1994)

21. Gough and Scott, 2007 S. Gough, W. Scott Higher Education and Sustainable Development: Paradox and Possibility Routledge, London; New York (2007)

22. Graybill and Shandas, 2010 J.K. Graybill, V. Shandas Doctoral student and early career academic perspectives R. Frodeman, J. Thompson Klein, C. Mitcham, B. Holbrook (Eds.), The Oxford Handbook of Interdisciplinarity, Oxford University Press, New York (2010), pp. 404-418

23. Grunwald, 2004 A. Grunwald Strategic knowledge for sustainable development: the need for reflexivity and learning at the interface between science and society International Journal on Foresight and Innovation Policy, 1 (1/2) (2004), pp. 150-167

24. Guth, $2006 \mathrm{~J}$. Guth The Bologna process: the impact of higher education reform on the structure and organisation of doctoral programmes in Germany Higher Education in Europe, 31 (3) (2006), pp. 327-338

25. Hansson, 2012 D. Hansson Unpacking Spinoza: sustainability education outside the Cartesian Box Journal of Sustainability Education, 3 (2012) http://www.jsedimensions.org/wordpress/wpcontent/uploads/2012/2003/HanssonJSE2012FinalVersion.pdf

26. Hirsch Hadorn et al., 2006 G. Hirsch Hadorn, D. Bradley, C. Pohl, S. Rist, U. Wiesmann Implications of transdisciplinarity for sustainability research Ecological Economics, 60 (1) (2006), pp. 119-128

27. Hirsch Hadorn et al., 2008 G. Hirsch Hadorn, H. Hoffmann-Riem, S. Biber-Klemm, W. GrossenbacherMansuy, D. Joye, C. Pohl, U. Wiesmann, E. Zemp Handbook of Transdisciplinary Research Springer, New York; Dordrecht (2008) 
28. Hirsch Hadorn et al., 2010 G. Hirsch Hadorn, C. Pohl, G. Bammer Solving problems through transdisciplinary research R. Frodeman (Ed.), The Oxford Handbook of Interdisciplinarity, Oxford University Press, Oxford (2010), pp. 431-452

29. Jahn, 2008 T. Jahn Transdisziplinarität in der Forschungspraxis (Transdisciplinarity in the Practice of Research.) M. Bergmann, E. Schramm (Eds.), Transdisziplinäre Forschung. Integrative Forschungsprozesse verstehen und bewerten, Campus Verlag: Frankfurt am Main, New York (2008), pp. 21-37 English translation (2010) available under:

http://www.isoe.de/fileadmin/redaktion/Downloads/Transdisziplinaritaet/jahn-transdisciplinarity2008.pdf

30. Kates et al., 2001 R.W. Kates, W.C. Clark, R. Corell, J.M. Hall, C.C. Jaeger, I. Lowe, J.J. McCarthy, H.J. Schellnhuber, B. Bolin, N.M. Dickson, S. Faucheux, G.C. Gallopin, A. Gräbler, B. Huntley, J. Jäger, N.S. Jodha, R.E. Kasperson, A. Mabogunje, P. Matson, H. Mooney, B. Moore lii, T. O'Riordan, U. Svedin Environment and development: sustainability science Science, 292 (5517) (2001), pp. 641-642

31. Klein, 1996 J.T. Klein Crossing Boundaries: Knowledge, Disciplinarities, and Interdisciplinarities University Press of Virginia, Charlottesville, Va (1996)

32. Krohn, 2008 W. Krohn Learning from case studies G. Hirsch Hadorn, H. Hoffmann-Riem, S. BiberKlemm, W. Grossenbacher-Mansuy, D. Joye, C. Pohl, U. Wiesmann, E. Zemp (Eds.), Handbook of Transdisciplinary Research, Springer, New York; Dordrecht (2008), pp. 369-383

33. Lieven and Maasen, 2007 O. Lieven, S. Maasen Transdisziplinäre Forschung: Vorbote Eines "New Deal" Zwischen Wissenschaft und Gesellschaft? (Transdisciplinary research: heralding a "new deal" between science and society?) GAIA Ecological Perspectives for Science and Society, 16 (1) (2007), pp. 35-40

34. Lozano, 2006 R. Lozano Incorporation and institutionalization of SD into universities: breaking through barriers to change Journal of Cleaner Production, 14 (9-11) (2006), pp. 787-796

35. Lozano et al., 2011 R. Lozano, R. Lukman, F.J. Lozano, D. Huisingh, W. Lambrechts Declarations for sustainability in higher education: becoming better leaders, through addressing the university system Journal of Cleaner Production (2011) http://dx.doi.org/10.1016/j.jclepro.2011.1010.1006

36. MacMynowski, 2007 D.P. MacMynowski Pausing at the brink of interdisciplinarity: power and knowledge at the meeting of social and biophysical science Ecology and Society, 12 (1) (2007)

37. Mainhard et al., 2009 T. Mainhard, R. van der Rijst, J. van Tartwijk, T. Wubbels A model for the supervisor-doctoral student relationship Higher Education, 58 (3) (2009), pp. 359-373

38. Max-Neef, 2005 M.A. Max-Neef Foundations of transdisciplinarity Ecological Economics, 53 (1) (2005), pp. 5-16

39. Mitrany and Stokols, 2005 M. Mitrany, D. Stokols Gauging the transdisciplinary qualities and outcomes of doctoral training programs Journal of Planning Education and Research, 24 (4) (2005), pp. 437-449

40. Montuori, 2011 A. Montuori Beyond postnormal times: the future of creativity and the creativity of the future Futures, 43 (2) (2011), pp. 221-227

41. Morin, 1999 E. Morin Seven Complex Lessons in Education for the Future URL (1999) http://unesdoc.unesco.org/images/0011/001177/117740eo.pdf

42. Morin and Kern, 1999 E. Morin, A.B. Kern Homeland Earth: a Manifesto for the New Millenium Hampton Press, Cresskill, N.J (1999)

43. Muhar and Kinsperger, 2007 A. Muhar, A. Kinsperger Implementierung inter- und transdisziplinärer Forschungsansätze in Graduiertenkollegs: Handlungsoptionen seitens der Universitäten (Implementation of Inter- and Transdisciplinary Research Principles in Doctoral Schools: options of action for universities) Zeitschrift für Hochschulentwicklung, 1 (1) (2007), pp. 93-109 
44. Muhar et al., 2006 A. Muhar, U. Vilsmaier, M. Glanzer, B. Freyer Initiating transdisciplinarity in academic case study teaching: experiences from a regional development project in Salzburg, Austria International Journal of Sustainability in Higher Education, 7 (3) (2006), pp. 293-308

45. Neuhauser et al., 2007 L. Neuhauser, D. Richardson, S. Mackenzie, M. Minkler Advancing transdisciplinary and translational research practice: issues and models of doctoral education in public health Journal of Research Practice, 3 (2) (2007)

46. Nicolescu, 1996 B. Nicolescu La Transdisciplinarité. Manifeste Editions du Rocher, Monaco [Paris] (1996)

47. Nowotny et al., $2001 \mathrm{H}$. Nowotny, P. Scott, M. Gibbons Re-thinking Science - Knowledge and the Public in an Age of Uncertainty Polity Press, Cambridge (2001)

48. OECD, 2010 OECD Higher Education for Sustainable Development OECD, Paris (2010)

49. Pohl and Hirsch Hadorn, 2007 C. Pohl, G. Hirsch Hadorn Principles for Designing Transdisciplinary Research Oekom Verlag, Munich (2007)

50. Pohl et al., 2010 C. Pohl, S. Rist, A. Zimmermann, P. Fry, G.S. Gurung, F. Schneider, C.I. Speranza, B. Kiteme, S. Boillat, E. Serrano, G.H. Hadorn, W. Urs Researchers' roles in knowledge co-production: experience from sustainability research in Kenya, Switzerland, Bolivia and Nepal Science and Public Policy, 37 (4) (2010), pp. 267-281

51. Rieckmann, 2012 M. Rieckmann Future-oriented higher education: which key competencies should be fostered through university teaching and learning? Futures, 44 (2) (2012), pp. 127-135

52. Rittel and Webber, 1973 H.W.J. Rittel, M.M. Webber Dilemmas in a general theory of planning Policy Sciences, 4 (2) (1973), pp. 155-169

53. Ryser et al., 2009 L. Ryser, G. Halseth, D. Thien Strategies and intervening factors influencing student social interaction and experiential learning in an interdisciplinary research team Research in Higher Education, 50 (3) (2009), pp. 248-267

54. Sachs, 2007 J. Sachs Bursting at the seams Reith Lectures 2007 (2007) http://www.bbc.co.uk/radio4/reith2007/lectures.shtml

55. Scholz, 2011 R.W. Scholz Environmental Literacy in Science and Society: from Knowledge to Decisions Cambridge University Press, Cambridge (2011)

56. Scholz et al., 2006 R.W. Scholz, D.J. Lang, A. Wiek, A.I. Walter, M. Stauffacher Transdisciplinary case studies as a means of sustainability learning: historical framework and theory International Journal of Sustainability in Higher Education, 7 (3) (2006), pp. 226-251

57. Steiner and Laws, 2006 G. Steiner, D. Laws How appropriate are two established concepts from higher education for solving complex real-world problems?: a comparison of the Harvard and the ETH case study approach International Journal of Sustainability in Higher Education, 7 (3) (2006), pp. 322-340

58. Swilling and Annecke, 2012 M. Swilling, E. Annecke Just Transitions: Explorations of Sustainability in an Unfair World United Nations University Press, Tokyo, Japan (2012)

59. Tainter, 2000 J.A. Tainter Problem solving: complexity, history, sustainability Population \& Environment, 22 (1) (2000), pp. 3-41

60. Teichler, 2006 U. Teichler Future challenges for doctoral studies in Germany U. Gorzka, U. Lanzendorf (Eds.), Europeanising Doctoral Studies, University Press, Kassel (2006), pp. 25-37

61. Tress et al., 2009 B. Tress, G. Tress, G. Fry Integrative research on environmental and landscape change: PhD students' motivations and challenges Journal of Environmental Management, 90 (9) (2009), pp. 2921-2929

62. UNESCO, 2006 UNESCO Framework for the United Nations Decade on Education for Sustainable Development UNESCO, Paris (2006) 
63. United Nations, 1993 United Nations Agenda 21: Earth Summit - the United Nations Programme of Action from Rio United Nations Department of Public Information, New York (1993)

64. Visser, $2006 \mathrm{~J}$. Visser Universities, Wisdom, Transdisciplinarity and the Challenges and Opportunities of Technology B.M. (Ed.), Perspectives on Higher Education in the Digital Age, Nova Science Publishers, Hauppage, NY (2006), pp. 187-205

65. Wall and Shankar, 2008 S. Wall, I. Shankar Adventures in transdisciplinary learning Studies in Higher Education, 33 (5) (2008), pp. 551-565

66. Wiek et al., 2011 A. Wiek, L. Withycombe, C.L. Redman Key competencies in sustainability: a reference framework for academic program development Sustainability Science, 6 (2) (2011), pp. 203-218

67. Woods, 2007 C. Woods Researching and developing interdisciplinary teaching: towards a conceptual framework for classroom communication Higher Education, 54 (6) (2007), pp. 853-866

68. Wright, 2004 T. Wright The evolution of sustainability declarations in higher education P.B. Corcoran, A.E.J. Wals (Eds.), Higher Education and the Challenge of Sustainability. Problematics, Promise, Practice, Springer, Netherlands (2004), pp. 7-19

69. Yin, 2002 R.K. Yin Case Study Research - Design and Methods Sage Publ., Thousand Oaks, Calif. (2002) 